\title{
Conocimiento y virtualidad en la sociedad de la ultramodernidad ${ }^{1}$
}

\section{Giulio Adinolfi}

Transnational Justice Center. New York

giulioadinolfi@hotmail.com

\section{Resumen}

En la sociedad de la ultramodernidad no toda información procura conocimiento. Los procesos mecánicos de asunción de las imágenes, sub specie stimuli se presentan con inaudita fuerza en la nueva sociedad virtualizada: aquí los procesos de razonamiento y de interpretación por símbolos se formalizan, anulando o reduciendo la portada efectiva del contenido, del espacio y del tiempo. Esto determina profundos cambios en las relaciones sociales considerado que la aplicación mecánica del poder de administración de la información no logra administrar correctamente contenidos discrepantes. El cambio radical de la nueva sociedad del conocimiento perdido a una sociedad del conocimiento recuperado se hace patente. La sectorialización de los símbolos podría proporcionar conocimientos de categoría capaces de dar contenidos a la forma de la información.

Palabras clave: sociedad de la comunicación, semiótica del espacio, símbolos, poder.

\section{Abstract. Virtuality and knowledge in ultra-modernity's society}

In the information society all information not offers knowledge. The mechanical processes of assumption of the images, sub specie stimuli shows up with unheard force in the new virtualized society: here the processes of reasoning and of interpretation for symbols are formalized, annulling or reducing the effective cover of the content, of the space and of the time. This determines deep changes in the social relationships considered that the mechanical application of the power of administration of the information is not able to administer correctly contained differing. The radical change of the new society of the lost knowledge to a society of the recovered knowledge becomes patent. The sectorialization of the symbols could provide knowledge of category able to give contained to the form of the information.

Key words: comunication society, semiotics of the space, symbols, power.

1. El presente trabajo ha sido presentado como ponencia en el seminario «Sociologia del cambio: le molteplici vie della modernizzazione sociale», organizado por la Universidad La Sapienza de Roma, el día 19 de dicembre de 2005, bajo el título «Conoscenza e virtualità: modernità e modelli di cambio sociale». En la presente edición, se ha añadido únicamente el ensayo de Umberto Eco, A passo di gambero (citado en la nota 4), en el que recoge algunos artículos que he citado a lo largo del trabajo. 


\section{Sumario}

Introducción

Pensar a las cosas por medio de imágenes

Virtualidad e igualación de diferentes contextos

Divisoria digital y mundo real

Información, comunicación y procesamiento del conocimiento

Complejidad de la ultramodernidad
Desorientación e individuación de lo real en la sociedad de la ultramodernidad

La identidad y el espacio como elementos básicos del proceso metodológico ultramoderno

Reinventar el espacio desde lo social: un reto sociológico

Conclusión

\section{Introducción}

En un reciente libro del estudioso Sartori, La sociedad teledirigida, se asume como tesis de fondo "que el vídeo está transformando al Homo sapiens, producto de la cultura escrita, en un Homo videns para el cual la palabra está destronada por la imagen. Todo acaba siendo visualizado. Pero ¿qué sucede con lo no visualizable (que es la mayor parte)? Así, mientras nos preocupamos de quién controla los medios de comunicación, no nos percatamos de que es el instrumento en sí mismo y por sí mismo lo que se nos ha escapado de las manos» ${ }^{2}$. El mismo Sartori escribe que, para el hombre actual, «las cosas representadas en imágenes cuentan más y pesan más que las cosas dichas con palabras. Y esto es un cambio radical de dirección, porque mientras la capacidad simbólica distancia al Homo sapiens del animal, el hecho de ver lo acerca a sus capacidades ancestrales, al género al que pertenece la especie del Homo sapiens» ${ }^{3}$. De forma parecida y más generalizada, también Umberto Eco critica el actual rol de la "tecnología de la comunicación» y considera que el desarrollo de Internet, con la consecuente potencia de las imágenes, está creando una multiplicación de efectos simbólicos en grado de producir más ambiguación en el significado de las "cosas», tanto que cada uno podrá poseer su propia enciclopedia aparentemente igual entre ellas pero con distintos significados interpretativos. Además, considera el semiólogo italiano, la sólida presencia de Internet, así como lo ha producido y lo está produciendo el televisor, creará más incomunicación y más problemas a la hora de asumir la información ${ }^{4}$.

2. Véase SARTORI Giovanni, Homo videns: la sociedad teledirigida, Madrid, Taurus, 1998, p. 11, traducción de Ana Díaz Soler, tit.or. Homo videns: televisione e post-pensiero, Roma-Bari, Laterza, 1997, p. 121.

3. Véase ibídem, p. 28.

4. Cfr., de esta forma, ECO Umberto, «Pochi navigano su molti canali: Si moltiplicano i sistemi per inviare informazioni. Ma non si sa bene che cosa metterci dentro», L'Espresso, periódico del Gruppo Editoriale L'Espresso, 20 de septiembre de 2001; él mismo, «Il medium precede il messaggio. I tecnici stanno inventando veicoli di straordinaria capienza senza sapere cosa metterci dentro", ivi, 5 de abril de 2001; él mismo, "Buone notizie dal web cinese. 
El fenómeno es generalmente considerado como un problema de comunicación que afecta a Internet y a las formas de producción de la comunicación en las nuevas tecnologías: se trata de una comunicación entre el mismo "campo» de la red y el exterior de la red, es decir que varían los códigos, y en general los contextos, para asumir el significado del mensaje comunicativo ${ }^{5}$. Se trata de la producción de mensajes a través de mensajes ${ }^{6}$.

\section{Pensar a las cosas por medio de las imágenes}

Estas actuaciones de las nuevas tecnologías en el entorno humano provocan cambios de paradigma en la forma de reflexionar acerca de las «cosas». Se crea una discrepancia entre información escrita y comunicación por medio de imágenes. Según los estudios semióticos, la información escrita posee en sí misma, y dependiendo del contexto, un significado oculto, que se puede encontrar interpretando los datos y relacionándolos con: 1) la fuente de emisión; 2) el recorrido que realiza la información, y 3) el mismo destinatario. Diversamente,

I burocrati cinesi non sanno che cosa censurare. Colpiscono a caso. Ma contro Internet lo Stato perderá», ivi, 16 de noviembre de 2000; él mismo, "Scrivete a tutti i miei indirizzi. Ma non fidatevi troppo. Ho cercato l'email di Dante Alighieri. Ne ho trovate 56. E 36 di Rushdie, 22 di Umberto Eco», ivi, 18 de mayo de 2000; él mismo, "Lo hacker è essenziale al sistema", ivi, 2 de marzo de 2000; él mismo, "Ma che cos'è questo postmoderno? Vedessi mai che sono due cose diverse? Mettere in dubbio l'eredità del passato o rivisitarlo con gioia», ivi, 6 de mayo de 1999; él mismo, "Un uomo che legge ne vale due Fungheggiano in Italia mille iniziative e progetti per incentivare la lettura: è una geografia di splendide invenzioni», ivi, espresso, n. 46; él mismo, «From Internet to Gutenberg. A lecture presented by Umberto Eco at The Italian Academy for Advanced Studies in America", 12 de noviembre de 1996, se puede consultar en Internet, <http://www.hf.ntnu.no/anv/Finnbo/ tekster/Eco/Internet.htm>; él mismo, "Autori e autorità», trabajo presentado a la conferencia sobre el rol del experto en la época de la información, celebrado en Bolonia del jueves 28 de febrero de 2002 al jueves 14 de marzo de 2002 (el texto está disponible en $<$ http://www.text-e.org/conf/index.cfm?switchLang=Ita\&ConfText_ID=11>; cfr., en particular, el reciente libro que recoge algunos de estos ensayos: ECO, Umberto, $A$ passo di gambero: guerre calde e populismo mediatico, Milán, Bompiani, 2006, p. 349, passim. Cfr. también un artículo publicado en Internet bajo el título «Umberto Eco se pierde en la red», en que se comenta una entrevista del autor al periódico alemán Welt, realizada el 1 de octubre de 2004 y donde se recogen diferentes comentarios a las afirmaciones del estudioso italiano <http://mangasverdes.es/2004/10/01/umberto-eco-se-pierde-en-internet/>.

5. Cfr. SARTORI Giovanni, Homo videns..., ob. cit., p. 63 y s. y, en referencia a la importancia del contexto, cfr. ECO, Umberto, Signo, Barcelona, Labor, 1988, p. 24, p. 30, p. 88-91, p. 94-96, p. 173 y s., p. 186-187.

6. Así, Eco, Umberto, Sette anni di desiderio (1977-1983), Milán, Bompiani, 2000, p. 134143 (1a ed. 1983), con esta locución, el semiólogo Eco indica todos aquellos mensajes que resultan ser una prolongación de mensajes gestuales, por ejemplo: el acto del ayuno como lucha política (en Italia el político Pannella) que se realiza para que la gente hable de esto, para que se llame la atención sobre el mensaje simbólico que se quiere comunicar. Existen dos mensajes, A y B, el primero es un acto, el segundo es un símbolo que comunica. A es dependiente de B, y B comunica consecuencial o diferentemente de A, pero B tiene vida propia, por lo que afecta a lo que ha comunicado tanto que se pueden extraer de B significados contrarios al acto $\mathrm{A}$. 
la comunicación visual se difunde a través de símbolos, imágenes que quieren expresar una sensación, información con ambigüedades, o concepto, o un conjunto de imágenes que originan un conjunto de conceptos ${ }^{7}$. El símbolo, que nace a través de la imagen, cuando viene asumido por el hombre presenta ya en sí mismo un mensaje: se tratará de analizar después si este mensaje encuentra su fundamento en el análisis de la fuente de emisión, recorrido y destinatario. El símbolo, entonces, no se limita a mera información, sino que puede evitar de informar sub specie stimuli para ofrecer contenidos en movimiento ${ }^{8}$. Por una parte, tenemos la estaticidad de la información, que puede llegar a ser comunicación una vez que se haya creado un código a través del cual se puede asumir el significado; por otra, la dinamicidad de la imagen, la cual multiplica las interpretaciones posibles, excepto cuando exista un acuerdo previo sobre el significado de las imágenes - por ejemplo, señales de tráfico, símbolos de carreteras, etc., y también en este caso se pueden presentar problemas entre diferentes "contextos», imaginamos un cartel de autopista de color azul en España y de color verde en Italia y verde también en Francia, el color puede intervenir para modificar el sentido adoptado, y alguien creerá que sigue en una autopista mientras se encuentra en una carretera nacional-. Esto impli$\mathrm{ca}$, pues, que cuando varía el espacio del origen de un mensaje (signo) se entiende mejor la diferencia entre información y comunicación que exprimen un proceso diferente de asunción del conocimiento?

7. En efecto, según Eco: «La información en el sentido de (b) [cantidad precisa de información seleccionada que ha sido de hecho enviada y recibida] puede ser calculada como: (b, i) el traspaso a través de un canal, de señales que ni hayan tenido alguna función comunicativa y que se presentan como meros estímulos, naturales o mecánicos; (b ii) el traspaso, a través de un canal, de señales que tengan una función comunicativa, es decir, han sido codificados como vehículos por alguna unidad de contenido"; véase ECO, Umberto, Trattato di semiotica gerenerale, Milán, Bompiani, 1975, p. 420, p. 62. Cfr., en relación con la función del signo, p. 73 y s. y p. 235 y s.; aún en relación entre información y símbolos, cfr. p. 222 y s., y 239 y s..; Cfr. Prieto, Luis J., Lineamenti di Semiologia. Messaggi e segnali, Bari, Laterza, 1971, p. 194 , p. 47-63 y p. 65-73. Aquí, obviamente, no consideramos la diferencia entre símbolos e imágenes según el distinto campo de transmisión.

8. Cfr. acerca de la importancia en la «nueva» cultura de los símbolos e imágenes, BRISSET MARTín, Demetrio E., «Fotografía, muerte y símbolo: aproximación desde la antropología visual», en Gazeta de Antropología, 2005, n. 21, disponible en <http://www.ugr.es/ - pwlac/ G21_01DemetrioE_Brisset_Martin.html>; KRAMER, Sybille, «Dialogicità telematica? Tesi sula comunicazione en Internet", Rivista Sociologia della Comunicazione, 1995, n. 24, p. 34-72; MOXEY, Keith, "Estética de la cultura visual en el momento de la globalización", en BREA José Luis (coord.), Estudios visuales: la epistemología de la visualidad en la era de la globalización, Madrid, Akal, 2005, p. 27-37; MALDONADO, Tomás, Entre lo real y lo virtual, Barcelona, Gedisa. 1994, p. 261, passim.

9. Estamos tratando de la diferencia entre significación y comunicación o, dicho de otra forma, según las palabras de Eco, entre una semiótica de la significación y una semiótica de la comunicación. La primera trata de la teoría de los códigos, la segunda, de la teoría de la producción de los signos. ECO, p. 14, cfr. en sentido parecido aunque analizando más la influencia del espacio sobre el mensaje LASH, Scott, URRY, John, Economías de signos y espacio, Buenos Aires, Amorrortu, 1998, p. 465, p. 13 y s. 


\section{Virtualidad e igualación de diferentes contextos}

Ahora bien, en la red de Internet y en las nuevas tecnologías comunicativas — digital e interacción televisiva, interacción satelital— que privilegian el instrumental visivo, ocurre lo mismo. Pero en Internet, además, varía también el tiempo considerado, su perspectiva diacrónica, y se pueden encontrar informaciones y comunicaciones que, no siendo solamente polisémicas, son de tiempos diferentes, de contextos diferentes, evocan hechos diferentes, porque una noticia de hace tres o cuatros años ha perdido su contexto y puede crear confusión cuando se presenta como actual, tal y como se realiza hoy en Internet ${ }^{10}$.

Escribía el sociólogo Mead que «[e]n el hombre la diferenciación funcional a través del lenguaje da lugar a un principio de organización completamente diferente que produce no solamente un tipo distinto de individuos, sino también una sociedad distinta» ${ }^{11}$. Sobre este punto, los actuales antropólogos de la comunicación y de la cultura están absolutamente de acuerdo ${ }^{12}$. Estos cambios están produciendo un cambio en la misma sociedad que se acostumbra a ver antes que a interpretar, se incentiva la memoria visiva a perjuicio de la memoria histórica, se apunta a la intuición antes que a la reflexión; a nivel sociológico acompañan la ruptura de barreras sociales y la creación de nuevas barreras entre quien sabe asumir esta nueva inteligencia y quien no lo sabe ${ }^{13}$. Generalmente, la experiencia en saber hacer algo es un motivo que se repite en cualquier cambio social, sin embargo «[1]a centralidad de Internet en muchas áreas de la actividad social, económica y política, se convierte en marginalidad para aquellos que no tienen o que tienen un acceso limitado a la red, así

10. Cfr. ZarZa NúNÉEZ, Tomás, «Derivas de la representación de lo cotidiano: la desaparición del momento decisivo. Tiempo online», Binaria: Revista de Comunicación, Cultura y Tecnología, 2004, n. 4, p. 1-9, disponible en <http://www.uem.es/binaria/columna_abierta/ archivos_columna/tomas_zarza_familia.pdf $>$.

11. Véase MEAD, George Herbert, $\overline{M i n d}$, self $\mho$ society: from the stand point of a social behaviorist self, Chicago-Londres, The University of Chicago press, 1934, p. 244.

12. Cfr., en este sentido, Morley, David, «Debate mediático: interpretando a las intepretaciones de las interpretaciones», en CURran, James, Morley, David, WalKerdine, Valerie (comps.), Estudios culturales y comunicación: Análisis, producción y consumo cultural de las políticas de identidad y el posmodernismo, Barcelona, Paidós, 1998, p. 447454; SPITULNIK, Debra, "Anthropology and Mass Media", Annual Review of Anthropology, 1993 , n. 22, p. 293-315, p. 296 y s.; BARBERO MARTIN, Jesús, «De la ciudad mediada a la ciudad virtual, transformaciones radicales en marcha», Telos, 1996, n. 44, dic.-feb., p. $15-22$, p. 17.

13. «Nos guste o no nos guste, podemos estar seguros que aquellas sociedades que usen de pleno las nuevas tecnologías de la comunicación, de acuerdo con mejores lenguajes y mejores máquinas, finalmente se impondrán a aquéllas que no lo hagan», véase YounG, J. Z., Doubt and Certainty in Science: A Biologist's Reflections on the Brain, Nueva York, Oxford University Press, 1950 cit. por BUDD, Richard W. «Información, interacción, intercomunicación: Tejiendo la red global. El impacto de Internet en el futuro de la educación», Zer, Revista de Estudios de Comunicación, traducción del inglés por José María Legarda, disponible en <http://www.ehu.es/zer/zer2/2artbudd.html\#anchor534920>. 
como para los que no son capaces de sacarle partido» ${ }^{14}$. En la realidad social actual, Internet, entre las nuevas tecnologías, es un hecho de masa y la red ha llegado a la mayor parte de las áreas de la actividad social. Quien quiera seguir viviendo en la sociedad de nuestro tiempo, tendrá que acostumbrarse a la sociedad de la red, a las nuevas tecnologías audiovisuales y a forjar el instrumental teórico-cultural adecuado para no encontrarse fuera de su tiempo y, consecuentemente, dejar de comprender muchas o pocas o diferentes "cosas». De una u otra manera, todos nos vemos afectados por la red. Este desarrollo de la modernidad, según Manuel Castells, se debe a la coincidencia histórica, hacia finales de los años sesenta y mediados de los setenta, de tres procesos independientes: la revolución de la tecnología de la información; la crisis económica tanto del capitalismo como del estatismo y sus reestructuraciones subsiguientes; el florecimiento de movimientos sociales y culturales, como el antiautarquismo, la defensa de los derechos humanos, el feminismo y el ecologismo. Castells afirma que «la interacción de estos procesos y las reacciones que desencadenaron crearon una nueva estructura social dominante, la sociedad de la red; una nueva economía, la economía informacional/global; y una nueva cultura, la cultura de la virtualidad real» ${ }^{15}$. Y es precisamente la virtualidad de lo real que termina con la implementación de las imágenes visuales y la creación de conceptos fáciles de entender, sencillos de captar, pocos esfuerzos mentales y palabras simples ${ }^{16}$. La lectura en Internet y en televisión - generalmente ofrecida por medio de tablas explicativas - se hace más rápida y el sentido de muchas expresiones se asume dependiendo del contexto en los que éste se realiza ${ }^{17}$. Por eso parece inevitable que nuestro futuro pase por la informatización y por la comunicación global en red. La comunicación en red y las tecnologías de la instantaneidad afectan a nuestra experiencia del tiempo y del espacio, y producen en los seres humanos sensaciones de deslocalización y destemporalización que nos obligan a replantearnos nuestras nociones de contexto, de presencia, de realidad, de virtualidad, de ausencia, de forma escrita, hablada, imaginada, $\operatorname{simbolizada}^{18}$. La propia imagen del yo —el yo

14. Véase CASTELls, Manuel, La galaxia Internet: reflexiones sobre Internet, empresa y sociedad, Barcelona, Plaza \& Janés, 2001, p. 275; cfr. sobre los cambios, HARVEY, David, La condición de la posmodernidad: investigación sobre los orígenes del cambio cultural, Buenos Aires, Amorrortu Editores, 1998, p. 401, p. 24-37.

15. Véase CASTELLS, Manuel, La era de la información. Economía, sociedad y cultura. Vol. 3: Fin de milenio, Madrid, Alianza Editorial, 1998, p. 370.

16. Cfr. ya en su tiempo la relación entre lenguaje de masa y televisión en el célebre análisis de ECO, Umberto, «La fenomenologia di Mike Buongiorno», en Eco, Umberto, Diario Minimo, Milán, Bompiani, 1963, p. 29-35.

17. Cfr., en este sentido, Maldonado, Tomás, Entre lo real y lo virtual, ob .cit., p. 43-45.

18. Cfr. en relación con la característica de la velocidad en la modernidad, VIRILIO, Paul, El arte del motor: aceleración y realidad virtual, Buenos Aires, Manantial, 1996, passim; él mismo, Velocita’ e politica: Saggio di dromologia, Milán, Multhipla, 1981, passim; él mismo, La Bomba informática, Madrid, Cátedra, 1999, passim. Según Giddens: «El tiempo de la vida se separa de la exterioridad del lugar en tanto que éste es socavado por la expansión de los mecanismos de desenclave. [...] el lugar ha quedado, más bien, invadido por mecanismos de desen 
reflejo como síntesis de nuestras participaciones en el mundo externo-y de nosotros mismos se ve afectada por la comunicación global, y se encuentra ante problemas para afirmar su propia identidad o su propia multiidentidad en la red - pensamos en los chats y en los nombres que adoptamos cuando adquirimos un correo electrónico, cuando nos registramos en un sitio de información o en los recientes blogs - ${ }^{19}$. Dentro de poco, las relaciones con los demás pasarán inevitablemente a través filtro de la red y vivir en sociedad será como vivir conectados ${ }^{20}$.

\section{Divisoria digital y mundo real}

Aunque todos nos veamos afectados por ella, no todos participamos activamente en la red. Los usuarios de Internet son muchos si se miran desde las expectativas de mercado y de negocio, pero son muy pocos si se miran desde el punto de vista del acceso masivo de la población mundial a estas tecnologías. Las barreras estructurales tales como la pobreza, el desarrollo económico desigual, el idioma, la tecnofobia aumentan aún más esta situa-

clave que recombinan las actividades locales en relaciones espaciotemporales de ámbito cada vez más amplio. El lugar se hace fantasmagórico. [...] el lugar no constituye el parámetro de la experiencia [...]. El lugar resulta, así, mucho menos significativo de lo que solía en cuanto referente externo para el tiempo de vida del individuo. La actividad espacialmente localizada acaba estando más y más unida al proyecto reflejo del yo", véase Giddens, Anthony, Modernidad e identidad del yo. El yo y la sociedad en la época contemporánea, Barcelona, Península, 1995, p. 302, p. 187-188, cfr. VIRnO, Paolo, Gramática de la multitud. Para un análisis de las formas de vida contemporáneas, Buenos Aires, Colihue, p. 205, p. 64 y s.; p. 79 y s.; cfr. LASH, Scott, URRY, John, Economías de signos (...), op. cit., p. 76-84.

19. En opinión de Giddens, el secuestro de la naturaleza exterior determina que «[...] un individuo puede sentirse particularmente despojado en momentos decisivos, pues es entonces cuando los dilemas morales y existenciales se presentan en forma apremiante. El individuo se enfrenta, por así decirlo, a un retorno de lo reprimido, probablemente carecerá de los recursos psíquicos y sociales que le permitan solucionar los problemas planteados», GIDDENS Anthony, Modernidad e identidad del yo..., ob. cit., p. 123; el secuestro de la experiencia "posee una gran complejidad interna, revela contradicciones y permite posibilidades de reapropiación. El secuestro, insistimos, no es un fenómeno que se produzca de una vez por todas y no represente un conjunto de fronteras sin fricciones. El lugar de la opresión, sus características excluyentes, comportan normalmente connotaciones de diferenciación y desigualdad jerárquica. Las fronteras de la experiencia secuestrada son líneas de fractura, fuerzas cargadas de tensiones y débilmente controladas; o, continuando con las metáforas, con campos de batalla, a veces de carácter directamente social, pero a menudo situados dentro del terreno psicológicos del yo», p. 213.

20. Cfr. De Kerckhove Derrick, Inteligencias en conexión. Hacia una sociedad de la web, Barcelona, Gedisa, 1999, p. 353, introducción y notas de Wade Rowland, «la conectividad es un estado humano casi igual que lo es la colectividad o la individualidad", y poco después, «la red, el medio conectado por excelencia, es la tecnología que hace explícita y tangible esta condición natural de la interacción humana», p. 25, cfr. en sentido parecido, él mismo, La piel de la cultura: investigando la nueva realidad electrónica, introducción de Christopher Dewdney, Barcelona, Gedisa, 1999, p. 254, p. 19 s. 
ción $^{21}$. El acceso a la red está reservado a unos pocos respecto a la población actual en el mundo e incluso, como matiza Castells, muchos de estos tienen el acceso limitado o no son capaces de sacarle partido. Esta disparidad entre quienes están conectados y los que no, crea una brecha social que Castells llama la «divisoria digital» ${ }^{22}$. Esta divisoria no se ciñe solamente al acceso o no a Internet, ya que en sí mismo no es una solución. Aunque las tendencias de desarrollo tecnológico parecen apuntar hacia la desaparición de esta diferencia y de las diferentes formas de acceso hasta una futura igualación, ésta podría perdurar fundamentalmente por dos motivos: 1) el primero de ellos es que el avance de la tecnología será un hecho para todos, lo cual hará que cuando el acceso a Internet sea una realidad para todo el mundo, las élites globales, como dice Castells, escaparán ya a un círculo superior del ciberespacio, con lo cual generarán una nueva divisoria tecnológica. Por eso, la revolución de las telecomunicaciones obliga a la sociedad entera a adaptarse a una nueva estructura de ámbito cultural, social y labo$\mathrm{ral}^{23}$. Sin embargo, no todos nos adaptaremos por igual a estas transformaciones; 2) el otro motivo es, con seguridad, el más grave. Castells habla de la «brecha de conocimiento» cuando hace referencia a esas personas que tienen acceso a la red pero que no sacan partido de ella, estas personas que no saben vivir de imágenes o que, aunque viviendo, prefieren el método clásico de pensamiento. Hablamos de «brecha de conocimiento» y no de brecha de información, eso porque, aunque hablemos de sociedad de la información y de sociedad del conocimiento, información y conocimiento, como ya hemos subrayados, no son sinónimos ${ }^{24}$.

21. Imaginamos la situación de China, en que todavía se realiza el control sobre Internet, control sobre acceso y publicación de material y visión del sitio, limitación idiomática, aunque últimamente éste se está desintegrando por efecto de la anarquía de Internet, que transmite también creatividad para romper las barreras virtuales, cfr., en este sentido, Eco, Umberto, «Buone notizie dal web cinese [...], ob. cit., passim; cfr. SORJ, Bernardo, GUEDES, Luís Eduardo y que se están afirmando como los más importantes estudiosos de las oportunidades perdidas que brinda la red y las nuevas tecnologías, en particular en La Exclusão Digital: problemas conceituais, evidências empíricas e politicas públicas, disponible en $<$ http://www.bernardosorj.com/pdf/exclusaodigital_problemasconceituais.PDF>, y también, Internet y pobreza, Unesco, 2005, disponible en <www.centroedelstein.org.br/ sorj/pdf/internetypobreza.pdf>.

22. Cfr., sobre este tema, BALLESTERO, Fernando, La brecha digital: el riesgo de exclusión en la sociedad de la información, Madrid, Fundación Retevisión, 2002, p. 174, en particular, p. 22 y s.

23. Cfr., al respecto, BECK, Ulrich, «La división del trabajo, la imagen del yo y los proyectos de vida: nuevos conflictos en familia», en BECK, Ulrich, BECK-GERNSHEIM, Elisabeth, La individualización. El invdividualismo institucionalizado y sus consecuencias sociales y políticas, Barceloma, Paidós, 2003, p. 367, p. 189-215; cfr., en sentido parecido, BECK, Ulrich, Un nuevo mundo feliz: la precariedad del trabajo en la era de la globalización, Barcelona, Paidós, 2000 , p. 270 , p. $25-30$, p. 64-69.

24. Este aspecto no es analizado por BALLESTERO, Fernando, La brecha digital..., sin embargo, es muy relevante teniendo en consideración las aportaciones de Habermas. 


\section{Información, comunicación y procesamiento del conocimiento}

Las nuevas tecnologías no transmiten una corriente inerte, sino información, comunicación, es decir, poder y posibilidad de desarrollo de una ideología ${ }^{25}$. Habermas, en su libro Ciencia y técnica como «ideología», citando a Marcuse en su crítica a Max Weber, explica como "la técnica es siempre un proyecto histórico-social y en él se proyecta lo que una sociedad y los intereses en ella dominantes tienen el propósito de hacer con los hombres y con las cosas» ${ }^{26}$. Este interés de dominio material está reflejado en el poder que soporta los mensajes que fluyen por la red. Circulan muchos mensajes pero el conocimiento es el resultado del tratamiento y la asimilación de esa información. El cerebro humano, antes de poder utilizar la información, necesita asimilarla, acomodarla, procesarla, enfrentándola con los conocimientos que ya posee, encajarla en su espacio-tiempo según una perspectiva subjetiva -memoria y experiencias del propio individuo - y según una perspectiva objetiva —el contexto de toda la sociedad-. Castells subraya que «el nuevo aprendizaje está orientado hacia el desarrollo de la capacidad educativa que permite transformar la información en conocimiento y el conocimiento en acción» ${ }^{27}$. Y es que el aprendizaje basado en Internet no es una cuestión meramente tecnológica. Para poder trabajar en Internet, es necesario desarrollar la capacidad de trabajar en red. Es una cuestión dianoética: un proceso de pensamiento y de desarrollo de la inteligencia práctica. Lo que premia, como dice Castells, es la habilidad para discernir qué buscar, cómo obtenerlo, cómo procesarlo y cómo utilizarlo. Así, el conocimiento como medio de trabajo llega a ser, además, una fuente de poder. Habermas, en su tercera tesis, decía que «los intereses que

25. Cfr. Althuser, que cita una expresión de Freud: «La ideología es una "representación” de la relación imaginaria de los individuos con sus condiciones reales de existencia», y después elabora sus tesis: Tesis 1: la ideología representa la relación imaginaria de los individuos con sus condiciones reales de existencia. Tesis 2: la ideología tiene una existencia material. La ideología interpela a los individuos como sujetos: «Esta tesis viene simplemente a explicitar nuestra última proposición: la ideología sólo existe por el sujeto y para los sujetos. O sea: sólo existe ideología para los sujetos concretos y esta destinación de la ideología es posible solamente por el sujeto: es decir por la categoría de sujeto y su funcionamiento" cfr. Althusser, Luis, Ideología y aparatos ideológicos del Estado, Buenos Aires, Nueva Visión, 1988, p. 84, versión consultada disponible en <http://www.ucm.es/info/eurotheo/ e_books/althusser/index.html>; cfr. HABERMAS, Jürgen, Ciencia y técnica como «ideología», Tecnos, Madrid, 1986, p. 181; que escribe en «las informaciones provenientes del ámbito del saber técnicamente utilizable penetran en las tradiciones y compiten con ellas, y de esta forma obligan a una reconstrucción de las interpretaciones tradicionales del mundo", p. 101; y poco después, "[...] pero de todos modos indica un ámbito de futuras oportunidades de disociar el comportamiento humano de un sistema de normas vinculadas a la gramática de los juegos de lenguaje e integrarlo en lugar de eso en sistemas autorregulados del tipo hombre-máquina por medio de un influenciamiento psicológico inmediato. Las manipulaciones psicotécnicas del conocimiento pueden ya hoy eludir el rodeo que pasa por la interiorización de unas normas susceptibles de reflexión», p. 105.

26. Véase Habermas, Jürgen, Ciencia y técnica..., ob. cit., 1968, p. 55.

27. Véase Castells, Manuel, La galaxia Internet.., ob. cit., p. 287. 
guían al conocimiento se constituyen en el medio o elemento del trabajo, el lenguaje y la dominación ${ }^{28}$. Así pues, los intereses que guían al conocimiento, según Habermas, se adhieren a las funciones de un yo, mediante procesos culturales en un mundo de vida social, que construye una identidad en el conflicto entre las solicitudes de instinto y las coerciones sociales. Para Habermas, estas realizaciones inciden, a su vez, en las fuerzas de producción que una sociedad acumula; en la tradición cultural merced a la cual una sociedad se interpreta a sí misma, y en las legitimaciones que una sociedad adopta o critica. De esta forma, Habermas entiende que el conocimiento acompaña inevitablemente a un interés y establece la distinción entre interés técnico, interés práctico e interés emancipador. El primero de ellos reside en el trabajo, a través del cual el hombre ejerce su imperio sobre la naturaleza; tiene que ver, pues, con las fuerzas productivas, y da fe de existencia en las ciencias empíricas. El lenguaje es el locus del interés práctico, a través del cual se desnuda la tradición cultural, requerida por las ciencias hermenéuticas, ocupadas de la relación entre el hombre y la sociedad. Razón instrumental y comprensión hermenéutica aúnan sus esfuerzos hacia la liberación del hombre, auspiciada por el interés emancipador que enraíza en el medio social del dominio y tiene su aplicación en el orden de las legitimaciones ${ }^{29}$. De esta forma, el saber crítico, a cuyo modelo atiende la teoría crítica de la sociedad, satisface al impulso del interés emancipador. $\mathrm{Y}$ es justo el interés emancipador que en las nuevas tecnologías viene a fallar, y la consecuente incapacidad de crear una política de la emancipación ${ }^{30}$. El problema de la divisoria digital que expone Castells es algo que no se mide en el número de conexiones, sino en las consecuencias que comportan, tanto la conexión como la falta de conexión. Internet es más que una tecnología, es una forma organizada que distribuye el poder de la utilización de los mensajes, de la no utilización de los mismos, del caos que pueden producir cuando están fuera de contexto - imaginamos el caso de encontrar una ley en Internet y después darnos cuenta que ha intervenido una modificación legislativa que obviamente no ha sido actualizada en el lugar en el que la hemos encontrado anteriormente-. Por tanto, conviene repetir que el elemento más importante no es el acceso ni la información en sí misma, sino la cantidad y la clase de conocimiento que ésta contiene y la capacidad de procesarlo ${ }^{31}$.

\section{Complejidad de la ultramodernidad}

Toda esta confusión implica, según las acertadas análisis de José Antonio Marina, que vivimos no solamente en la era de la información, sino también en la era

28. Véase Habermas, Jürgen, "Conocimiento e Interés», en Ciencia y técnica..., ob. cit., p. 174.

29. Cfr. Habermas, Jürgen, Conocimiento e interes, Madrid, Taurus, 1989, p. 348, p. 64 y s., p. 151 y s.

30. Según como la entiende Giddens, cfr. GIDDENS, Anthony, Modernidad e identidad del yo..., ob. cit., p. 266-271, p. 271 y s., p. 282 y s.

31. Cfr.. Castells, Manuel, La galaxia Internet..., ob. cit., p. 297-298. 
de la fragmentación y de la complejidad en que podría resultar posible el proyecto de la ultramodernidad como superadora de los esquemas simbólicos modernos y, sobre todo, postmodernos. Este proyecto aboga por una neotemporización social que se articula sorprendentemente en la vieja pretensión unificadora del tiempo histórico. Se intenta, así, hacer desaparecer el discurso de la multiplicidad de los tiempos sociales considerándola un vestigio o, incluso, una rémora, del pasado postmoderno, y se postula un nuevo tiempo histórico, universal, que, una vez más, dota de sentido general a todo el quehacer humano ${ }^{32}$. El proyecto trata de concebir como inevitable u oportuno este cambio en la asunción de la comunicación y elaborar las condiciones efectivas para que todos o la mayoría de la población puedan seguir situados en su contexto ${ }^{33}$. Situación seguramente no fácil ante la fragmentación del mundo moderno - primer mundo, segundo mundo, tercer mundo, cuarto mundo y hay quien aboga por el quinto mundo, así como por la primera modernidad, la segunda modernidad, la tercera modernidad, la postmodernidad, la ultramodernidad, la sobremodernidad, etc.

Conviene aquí preguntarnos: ¿Cómo se puede plantear una extensión de la ultramodernidad, es decir, la asunción del discurso de la multiplicidad? Repetimos, estamos aquí preguntándonos no si se puede, el an, sino, admitiendo que se puede, porque sería oportuna o necesaria, es decir cómo se puede, el quomodo.

\section{a) Cambio cultural y modelos de sociedades: el rol del poder}

La comunicación concurre a un cambio cultural, cambio que ha sido analizado por la semiótica de la cultura, cuyo máximo representante de la escuela de Tartu-Moscú es Lotman. Este autor analizó como pueden producirse más modelos de cultura en un mismo ámbito geográfico, en un mismo período histórico, realizando investigaciones estructurales. Escribe Lotman:

La cultura está en diálogo constante con el espacio exterior a ella, estructurándolo según su imagen y semejanza. Pero este diálogo es existencialmente importante también para la cultura misma, en su curso la cultura obtiene y desarrolla su identidad (su mismidad): cuantas más relaciones exteriores, tanto más variadas son, tanto más rica es, a fin de cuentas, la cultura. Pero todavía más importancia posee el diálogo como proceso intracultural. Antes ya se mencionó la importancia de la autocomunicación (la comunicación en el canal

32. Cfr. Marina, José Antonio, Crónicas de la ultramodernidad, Barcelona, Anagrama, 2000, p. 264 , p. 23 y s., p. 33 y s. p. 65 y s., passim, cfr., en sentido parecido por lo que afecta a la cultura visiva, MiRZOEFF, Nicholas, «Libertad y cultura visual: plantando cara a la globalización», en BREA, José Luis (coord.), Estudios visuales: la epistemología de la visualidad en la era de la globalización, Madrid, Akal, 2005, p. 161-172; cfr. también sobre la necesidad de aprehender y divulgar las herramientas del cambio histórico actual, VIRNO, Paolo, Gramática de la multitud..., ob. cit., p. 33 y s.

33. Cfr. Marina, José Antonio, Crónicas de la ultramodernidad, ob. cit., p. 87 y s. 
"YO - YO») en la cultura. El resultado de la autocomunicación es, por un lado, la ramificación del «YO» en el $Y O$ transmisor y el $Y O$ receptor de la información (por ejemplo, la ramificación en el tiempo, como los diarios, los apuntes mnemónicos, etc.), por otro lado, la autocomunicación es un recurso del mantenimiento constante de la autoidentidad ${ }^{34}$.

Esto implica que, al lado de una cultura general, existen culturas particulares, propias del diálogo entre yo y yo. Internet y, en su tiempo, la televisión acrecen la cultura particular creando lo que se puede definir como fragmentos particulares de una cultura general ${ }^{35}$. El papel de la cultura siempre ha sido organizar los elementos y las relaciones que se constituyen en nuestro entorno. Es una acción informativa y, por tanto, necesariamente deformativa cuando se presenta en un período de cambio cultural en el que las fronteras de la deconstrucción se mezclan con las fronteras de la reconstrucción ${ }^{36}$. Es siempre una acción dinámica y constantemente adaptativa. De este esquema parcialmente lineal, se presenta la variabilidad metafórica, es decir que, dado que en Internet no sólo circula información, cultura, sino que al haberse convertido la información en la mayor fuente de poder, lo que fluye también es poder, consecuentemente, circula el poder del desorden, el poder de la manipulación, el poder de la atención, el poder de la desinformación sobre lo actual, el poder como control virtual ${ }^{37}$. La circulación del poder es paralela al intercambio de capitales y conocimientos científicos (ambos convertidos en mercancías transables en el mercado) y se realiza dentro de un mercado único, sin fronteras, de todos los países del mundo que tengan algo que ofrecer en el mercado mundial (de libre competencia) ${ }^{38}$.

34. véase LOTMAN, Iuriï Mijaïlovich, «La semiótica de la cultura en la Escuela semiótica de Tartu-Moscú», disponible en <http://www.ugr.es/ - mcaceres/Entretextos/entre5/mijail5.htm>.

35. Cfr. sobre los fragmentos particulares también del mismo LOTMAN, Iuriï Mijaïlovich., «El símbolo en el sistema de la cultura», Revista Electrónica Semetstral de Estudios, noviembre de 2003, n. 2, disponible en <http://www.ugr.es/ - mcaceres/Entretextos/entre2/escritos4.htm\#*>.

36. Cfr. Habermas, Jürgen, Ciencia y técnica..., ob. cit., que afirma: «La solución de tareas técnicas no está referida a la discusión pública, ya que lo único que ésta haría sería problematizar las condiciones marginales del sistema dentro de las cuales las tareas de la actividad estatal se presentan como técnicas. La nueva política del intervencionismo estatal exige por eso una despolitización de la masa de la población. Y en la medida en que quedan excluidas las cuestiones prácticas, queda también sin funciones la opinión pública política. En cualquier caso, el marco institucional de la sociedad sigue siendo todavía algo que no se identifica con los subsistemas de acción racional con respecto a fines. Su organización sigue siendo una cuestión de la práctica ligada a la comunicación, y no solamente un problema técnico, aunque la técnica sea de cuño científico. De ahí que la suspensión de las cuestiones prácticas que lleva aneja la nueva forma de dominación política sea algo que no resulta comprensible sin más. El programa sustitutorio legitimador del dominio deja sin cubrir una decisiva necesidad de legitimación: ¿Cómo hacer plausible la despolitización de las masas a estas mismas masas? Marcuse podría responder: en este punto la ciencia y la técnica adoptan también el papel de una ideología», p. 85-86.

37. En este sentido, véase HARDT, Michael, NEGRI Antonio, Impero. Il nuovo ordine della globalizzazione, Rizzoli, Milán, 2002, p. 451, p. 39 y s.

38. Cfr. ibídem, 26 y s.; p. 157-160, p. 303 y s. 
Todo esto ha determinado un cambio en el desarrollo que ya no se presenta tan lineal: mientras el modelo de la sociedad industrial se caracterizaba por la centralización de los medios de producción, la distribución masiva de objetos estandarizados, la especialización de tareas y su control jerarquizado, ahora la búsqueda del control sobre la producción y el aumento de productividad determinan el surgimiento del neotaylorismo, el neofordismo ${ }^{39}$, que logran la producción de mercancías estandarizadas en grandes series, la reducción de los costos de fabricación y un aumento del ritmo de trabajo, fuera del control nacionalizado que ahora más bien se presenta como un control imperial en el que no existe centro ni márgenes ${ }^{40}$. Esta elaboración no lineal y más bien vertical es de importancia clave, dato que Castells ve en la crisis de los modelos de desarrollo económico, tanto capitalista como estatista, el impulso para su reestructuración paralela - y virtual — a partir de mediados de los años setenta. Los valores clásicos han cambiado con la llegada de las tecnologías de la instantaneidad. En la década de 1990, la tecnología de la información (telecomunicaciones, computadores en red, etc.) ha permitido desarrollar nuevas formas de organización del trabajo, al hacer posible la flexibilización de los tipos de contrato, de la localización del trabajo y del horario de trabajo, con lo que se ejercen nuevas formas de control dentro de la producción y un incremento de la productividad ahora independiente de la expansión de las horas de aportación de trabajo y centrado ya, no como el taylorismo en la producción masiva de objetos estandarizados mediante la extrema división del trabajo en tareas especializadas, sino en la calidad y la innovación tecnológica por medio de reunificación de funciones en los niveles superiores ${ }^{41}$.

\section{b) Cambio cultural y modelos de sociedades: el rol de la economía supranacional}

Este modelo de trabajo en la nueva economía basada en la información es el de una mano de obra nuclear, formada por profesionales que se basan en la información, que, aunque mejor pagada y más estable, está sometida a la movilidad por la reducción del período de vida laboral —imaginamos el caso del contrato de teletrabajo que en Italia se ha trasformado como el primer

39. Aquí también se pueden ver las influencias de las doctrinas económicas en las doctrinas políticas y político-criminales, cfr. prefacio de Toni Negri en DE GIORGI, Alessandro, Tolerancia cero. Estrategias y práticas de la sociedad de control, Barcelona, Virus Editorial, 2005, p. 183, p. 27-33, cfr. también DE GIORGI, Alessandro, Il Governo dell'eccendenza: postfordismo e controllo della moltitudine, prefacio de Alesandro Melossi, Verona, Ombre Corte, p. 2002, p. 181; WACQUANT, Loïc, Simbiosi mortale: neoliberalismo e politica penale, Verona, Ombre Corte, 2002, p. 138, passim, cfr. BERGALli, Roberto, «Globalización y control social: post-fordismo y control punitivo», Sistema, Revista de Ciencias Sociales, 2001, n. 160 , p. $107-124$.

40. Cfr., en este sentido, Hardt, Michael, Negri, Antonio, Impero..., ob. cit., p. 26-30.

41. Cfr., de esta forma, BECK, Ulrich, "Capitalism Without Work», en Dissent, 1997, Winter, p. $51-56$, p. 52 . 
trabajo, entre los registrados y el negro, a tiempo determinado de tres o seis meses para una persona que se introduce en el mundo laboral-, en el que los profesionales son reclutados para formar parte del núcleo de base de la empresa Así, este sistema de subempleo permitido por la tecnología informacional aumenta la productividad también a costa de los trabajadores, ya que las ventajas están en que la empresa se ahorra los riesgos de producir más de lo que la demanda exige, al comprar a los contratistas sólo lo necesario, sustituye puestos de trabajo de manera más fácil para cumplir con las nuevas exigencias tecnológicas, y las instalaciones productivas son usadas de un modo más compacto, intensivo y prolongado, lo que ahorra costos de mantenimiento ${ }^{42}$.

En este nuevo sistema económico mundial, el desarrollo tecnológico y científico, especialmente - pero no únicamente- en lo relativo a comunicaciones e informática, permite la formación de un mercado mundial que se salta los límites de las fronteras nacionales ${ }^{43}$. La lógica de la cooperación y la fuente abierta abarca a los sectores económicos de Internet. Los portales de Internet venden información y obtienen otras informaciones de sus clientes que luego serán reutilizadas por ellos. Por tanto, los clientes son también productores. Este intercambio comunicativo entre productores y consumidores productores ayuda a los portales a modificar constantemente sus productos y servicios. Es una práctica empresarial orientada hacia el consumidor en la que la capacidad para interactuar con los consumidores como fuente de información se convierte en un elemento fundamental del modelo de empresa. Castells habla de este proceso e insiste en que «[1]a interacción entre productores y consumidores productores en un proceso compartido de rendimientos crecientes beneficia a todos aquellos que participan en la red ${ }^{44}$. Es, por tanto, un intercambio de información que se traduce en beneficio económico: en poder. Así, el poder se vuelve, y en parte se ha vuelto, algo inmaterial ${ }^{45}$. Entonces, si, para Castells, en una sociedad informacional el poder queda inscrito en los códigos culturales mediante los cuales las personas y las instituciones conciben la vida y toman decisiones, incluidas las políticas, significa que el nuevo poder ha cambiado la cultura de tal manera que se puede hablar de una nueva cultura ${ }^{46}$. El desorden parece difundirse y, con él, la manipulación: con una masa increíble de información se puede esconder la información relevante, se puede resaltar

42. Cfr. ibídem, p. 54. Cfr., en el mismo sentido, BECK, Ulrich, Un nuevo mundo feliz..., ob. cit., p. 134 y s.

43. Cfr. Habermas, Jürgen, «El valle de lágrimas de la globalización», en Claves de Razón Práctica, 2001, n. 109, p. 4-11; él mismo, La constelación postnacional, Barcelona, Paidós, 2000, en particular «La constelación postnacional y el futuro de la democracia», p. 81-145, p. 93 y s. Cfr., en sentido parecido, HARDT, Michael, NeGrI, Antonio, Impero..., ob. cit., p. 33 y s.

44. Cfr. CaStells, Manuel, La galaxia Internet..., ob. cit., p. 121.

45. Ya profetizado por Habermas en «Ciencia y Técnica» cuando analizaba la obra de Marcuse, supra.

46. Cfr. HarveY, David, La condición de la posmodernidad..., ob. cit., p. 87 y s. 
aquélla irrelevante, en suma, se puede evitar que la información se traduzca en comunicación y conocimiento acerca del contexto en el que se vive.

\section{c) Cambio cultural y modelos de sociedades: la descontextualización del Yo}

En el cambio cultural, seguramente el matrimonio entre lenguaje y electricidad ha sido el aspecto más relevante de las nuevas tecnologías. Se ha pasado de la página del libro a la pantalla del ordenador. Es el paso del texto físico al hipertexto electrónico ${ }^{47}$. El texto, el libro y sobre todo la revolución que causó la imprenta, supusieron el paso de la tradición oral a la tradición escrita y, lo que es más importante, del pensamiento único al pensamiento privado. El libro abrió la puerta del espacio mental, de la imaginación personal privada; mientras la cultura oral estableció un espacio cognitivo, una organización mental, se presentaba como una estructura mental colectiva. No era personal. Era un pensamiento único, unívoco, que transmitían sin ponerlo en tela de juicio. El libro crea la privacidad, se convierte en refugio del saber - lo que en época moderna pondrá el intelectual ante la duda del individualismo o del colectivismo o, según el análisis de Eco, entre los apocalípticos que predican una cultura cerrada y los integrados que proponen la apertura de la cultura a la masa -48 . En este proceso evolucionista, la principal innovación que aporta el hipertexto, open book o el texto como imagen, es el método de organización en sí, fiel reflejo de la estructura asociativa empleada por la mente humana para relacionar conceptos, y su automatización. En el primer caso se trata de haber creado una privacidad colectiva, es decir, vuelve el espacio cognitivo, a través de un medio considerado generalmente individual y cerrado, el texto escrito. Esto produce la confusión típicamente moderna entre público y privado, socialidad y privacidad, la descontextualización, yo y el yo reflejo, in suma, la creación del relativismo moderno ${ }^{49}$. En el segundo caso, se presenta como una tecnología cuya característica principal es su capacidad para emular la organización asociativa de la mente humana. Intenta reproducir una típica estructura dialógica $^{50}$ que exige una cierta actividad por parte del usuario. Así, la interactividad del usuario se denomina metafóricamente navegación, exploración de un hipertexto. Pero el hipertexto no es en sí la tecnología; como dice Castells: «el hipertexto no es producido por el sistema multimedia, utilizando Internet

47. Cfr., sobre la nueva forma de construcción del texto escrito en Internet, PEETERS, Hugues, CHARlier, Philippe, "Contribuitions à une théorie du dispositif", en AA.VV. Le dispositif. Entre usage et concept, París, CNRS editions. 1999, p. 297, p. 15-23; y también de los mismos, «Pour une sémio-pragmatique des hypertextes multimédia: proposition théorique de catégories d'analyse pertinentes», disponible en <http://www.comu.ucl.ac.be/reco/grems/ hugoweb/semhptxt.htm>.

48. Cfr., en este sentido, el debate empezado en los años sesenta y resumido en todas sus múltiples formas por ECO, Umberto, Apocalittici e integrati, Milán, Bompiani, 2001, p. 385, p. 23 y s.

49. En este sentido, VIRno, Paolo, Gramática de la multitud..., ob. cit., p. 101 y s.

50. Cfr. Kramer, Sybille, "Dialogicità telematica?», ob. cit., p.. 62 y s. 
como medio de llegar a todos nosotros; más bien es algo que nosotros mismos producimos al utilizar Internet para absorber la expresión cultural en el mundo multimedia y más allá. Sin duda, ese era el sentido del Xanadú ideado por Ted Nelson, y eso es lo que deberíamos haber entendido" ${ }^{51}$.

Entonces, la nueva cultura de la comunicación visiva por una parte provoca la dualidad entre público y privado en la utilización del medio cultural aislando el yo, y, por otra parte, intenta poner remedio imitando los mismos procesos mentales del yo social. De aquí deriva el fenómeno moderno de desorientación en la modernidad ${ }^{52}$.

Ahora bien, tras haber determinado el campo del proceso cultural de la modernidad a la ultramodernidad, la desorientación llega a ser el objeto concreto que parece impedir el discurso de la ultramodernidad. ¿Cómo puede afirmarse el discurso de la ultramodernidad? Simplemente, utilizando el factor heurístico que emana de la desorientación — así como Jonas intentaba revitalizar la seguridad y el primario principio de responsabilidad través de una heurística del temor ${ }^{53}$.

\section{Desorientación e individuación de lo real en la sociedad de la ultramodernidad}

Comunicación, sentido, contexto, pero también desinformación, incomunicación creencias erróneas, la nueva cultura tecnológica se presenta como un poderoso instrumento de conocimiento y aprendizaje, pero también como un poderoso instrumento de mentira y desinformación. ¿A quién corresponde la tarea de separar el grano de la paja? ${ }^{54}$. En cuestiones de información, probablemente ésta sea la tarea de los nuevos periodistas que trabajan en y para

51. Véase CASTELls, Manuel, La galaxia Internet..., ob. cit., p. 230.

52. Escribe Virilio que: «con el desarrollo de las autopistas de la información, nos encontramos ante un fenómeno nuevo: la desorientación», véase VIRILIO, Paul, «Peligros, riesgos y amenazas», en RAMONET, Ignacio (ed.), Internet, el mundo que llega. Los nuevos caminos de la comunicación, versión española de Juan María López de Sa, Madrid, Alianza Editorial, 1998 , p. 303, p. 155-160, p. 156. En el mismo sentido, afirma Castells «son nuestras mentes - y no nuestras máquinas - las que procesan la cultura, sobre la base de nuestra propia existencia», CASTELls, Manuel, La galaxia Internet..., ob. cit., p. 229.

53. A través del temor, se instala en las personas un sentido de supervivencia que impone utilizar aquel temor para reflexionar sobre las causas que podrían limitarlo. Es decir que cada uno tendría que preguntarse: «¿Cuáles son los efectos de mis acciones y de mis selecciones sobre toda la humanidad?». Este temor se traduce en un control sobre los efectos, tal y como se realiza habitualmente, pero también en un pensamiento preventivo sobre las acciones que vamos a realizar. JONAS, Hans, Il principio responsabilita: un'etica per la civilta tecnologica, a cargo de Pier Paolo Portinaro, Turín, Einaudi, 1993, p. 291, p. 33-36; escribe Jonas que «[...] solamente la prevista desfiguración del hombre nos ayuda a forjarnos la idea de hombre que ha de ser preservada de tal desfiguración; y necesitamos que ese concepto se vea amenazado — con formas muy concretas de amenaza - para, ante el espanto que tal cosa nos produce, afianzar una imagen verdadera del hombre», p. 41.

54. Cfr. Eco, Umberto, A passo di gambero..., ob. cit., p. 46 y s., p. 94 y s. sobre los censores de Internet, in suma el control de la anarquía del web. 
Internet. Periodistas que ya no podrán ser sólo eso; que tendrán que completar su formación con nuevos protocolos de redacción (de la pirámide invertida al hipertexto), de construcción de noticias (de estructuras lineales a fragmentarias), de relación con sus públicos, de tratamiento de la información. Una figura nueva aparece bajo el nombre de «comunicador digital». Su perfil está aún por definir, pero si retomamos un ensayo de Vanneaver Bush de 1945, podemos encontrar en él aportaciones importantes: "Aparecerá una nueva profesión, la de los trazadores de senderos, es decir, aquellas personas que encuentran placer en la tarea de crear senderos de información útiles que transcurran a través de la inmensa masa del archivo común de la humanidad» ${ }^{55}$.

La desorientación es un producto individual, y la desorientación social es el resultado de las combinaciones de los productos individuales. Resaltando la conciencia social, se podría reducir la desorientación individual. Se trata de utilizar los mismos medios de genealogía de la moral que emplea la nueva cultura tecnológica — probablemente inconscientemente - para difundir un sentido social ${ }^{56}$. El proyecto de la ultramodernidad está en la conciencia de lo social sobre la conciencia desorientada del individuo ${ }^{57}$. Hay que apuntar sobre las bases del yo público para influir sobre el yo privado ${ }^{58}$. Entonces, la inteligencia colectiva, que consideramos propia del grupo "conectado", "no es la fusión de las inteligencias individuales en una especie de magma comunitario, sino, por el contrario, la valoración y el impulso mutuo de las particularidades de cada uno» ${ }^{59}$. Se tiene que recuperar la conciencia social propia de la tradición oral, y esto se puede hacer incentivando las «tribus» en la red —los

55. Véase Bush, Vanneaver, «Cómo podríamos pensar», Revista de Occidente, 2001, n. 239, marzo, p. 53-71, p. 49, disponible en <http://biblioweb.sindominio.net/pensamiento/vbushes.html>, traducción de Ernesto Arbeloa título original, «As We May Think», publicado originarimente en The Atlantic Monthly, 1945, n. 176, p. 101-108, disponible en <http://www.ps.uni-sb.de/ -duchier/pub/vbush/vbush.txt>.

56. Así como trataba Eco en su «manifiesto», «Para una guerrilla semiológica», en EcO, Umberto, La estrategia de la ilusión, Barcelona, Lumen, 1999, p. 137-146; cfr., en sentido parecido sobre la formas de neogenealogía de la moral, JONAS, Hans, Il principio responsabilita..., ob. cit., p. 85 y s., passim.

57. No nos olvidemos que Durkheim apuntaba sobre la conciencia colectiva o social para reducir la "contrariedad» individual. Cfr. DURKHEIM, Emile, Las reglas del método sociológico, edición de Gregorio Robles Morchón, Madrid, Biblioteca Nueva, 2005, p. 270. Escribe el sociólogo francés: «La conciencia pública impide todo acto que la ofenda, por la vigilancia que ejerce sobre la conducta de los ciudadanos y las penas especiales de que dispone. En otros casos la coacción es menos violenta, pero existe», p. 44, y poco después, "[...] los hechos sociales, por el contrario, presentan de una manera más natural e inmediata todos los caracteres de la cosa. El derecho existe en los códigos, los movimientos de la vida cotidiana se reflejan en las cifras de la estadística, en los monumentos de la historia, las modas en los vestidos, los gustos en las obras de arte. Por su misma naturaleza tienden a constituirse con independencia de las conciencias individuales, pues las dominan", p. 85.

58. Cfr. como en estos términos sea posible crear una política de la emancipación, GIDDENS, Anthony, Modernidad e identidad del yo..., ob. cit., p. 273 y s.

59. Véase LEVY, Pierre, "Construir la inteligencia colectiva», en RAMONET, Ignacio (ed.), Internet, el mundo que llega..., ob. cit., p. 101-106, p. 103. 
grupos de discusiones, que comparten los mismos intereses-, creando una geografía de Internet. Se trata de crear las listas de las «tribus» afirmadas o que han monopolizado su entorno y han "ganado sobre las demás». Ordenar la geografía igual como ha sido ordenada la historia, según la teoría evolucionista de Darwin. Atribuyendo a la fuerza física o a las capacidades objetivas — velocidad, número de miembros, condiciones de vida, etc. - también la fuerza comunicativa - como capacidad de promocionarse, de difundirse, de actualizarse, también de cultivar las modas ${ }^{60}$ — según las formas de supervivencia y las necesidades vitales del individuo, así como planteado por la lectura de Nietzsche junto a Freud ${ }^{61}$. Se trata de conjugar la teoría evolucionista, limitada a la actitud bruta e incapaz de ofrecer el nivel metafórico, con las interpretaciones morales y psicológicas que derivan de Nietzsche y Freud y situadas detrás del poder.

$\mathrm{Si}$, según Contreras, el individuo es un "trabajador del saber», entonces se tiene que utilizar el saber producido por el individuo para darle conciencia de las relaciones sociales. "Reciclamos el principio capital-trabajo y lo convertimos en información-conocimiento; el factor de producción es el saber del individuo en la nueva economía de la información»" ${ }^{62}$. Frente a la estructura de los medios de comunicación clásicos, en la que hay una relación de uno a muchos y una separación entre los centros emisores y los receptores pasivos y aislados entre ellos, aparece un nuevo dispositivo comunicativo, una nueva estructura basada en la relación de muchos a muchos. «En el ciberespacio cada uno es potencialmente emisor y receptor, en un espacio cualitativamente diferenciado, no fijo, moldeado por los participantes, explorable ${ }^{63}$.» Se trata de utilizar Internet y la virtualidad que origina como «un instrumento al servicio de la cohesión social mediante el intercambio de conocimientos y el empleo de las capacidades» ${ }^{64}$. Los nuevos poderes están en manos de quienes poseen las claves de las innovaciones tecnológicas, de quienes regulan los procesos de información y de comunicación. Según Castells, «[...] la era Internet ha sido anunciada como el fin de la geografía. De hecho, Internet tiene una geografía propia, una geografía hecha de redes y nodos que procesan flujos de información generados y controlados desde determinados lugares. La unidad es la red, por lo que la arquitectura y la dinámica de varias redes constituyen las fuentes de sig-

60. Al fin y al cabo, es lo que se está intentado hacer a través de los grupos en Internet, por ejemplo, Google con sus grupos, con Google Schoolar en el intento de organizar los textos publicados en Internet, etc.

61. Cfr. Foucault, Michel, Nietzche, Freud, Marx, Barcelona, Anagrama, 1970, p. 57, passim; en sentido parecido, también, GuATTARI, Félix, Deleuze, Gilles, El Anti-Edipo: capitalismo y esquizofrenia, Barcelona, Paidós, 1973, p. 422, p. 221 y s., passim.

62. Véase CONTRERAS, Fernando R., Nuevas fronteras de la infografía: análisis de la imagen por ordenador, Sevilla, Mergablum, 2000, p. 271, p. 52.

63. Véase LEVY, Pierre, "Construir la inteligencia colectiva», en RAMONET, Ignacio (ed.), Internet, el mundo que llega..., ob. cit., p. 104.

64. Véase LEVY, Pierre, "Construir la inteligencia colectiva», en RAMONET, Ignacio (ed.), Internet, el mundo que llega..., ob. cit., p.106. 
nificado y de función de cada lugar. El espacio de flujos resultante es una nueva forma de espacio: establece conexiones entre lugares mediante redes informáticas telecomunicadas y sistemas de transporte informatizados. Redefine la distancia pero no suprime la geografía ${ }^{65}$.

\section{La identidad y el espacio como elementos básicos del proceso metodológico ultramoderno}

El nuevo razonamiento y la metodología cultural basada en el ámbito del antiguo modelo económico, social y cultural, no es válido para el nuevo espacio inmaterial representado por Internet y su nuevo proceso cultural. La conciencia completa de una "heurística de la desorientación», realizada a través de una organización o de una procedimentalización nietzscheana de la historia, podría crear la justa relación entre identidad y espacio, que, según creemos, representa el problema más importante en el discurso de la ultramodernidad ${ }^{66}$. Además ésta, como hemos señalado, ya no es una cuestión "sólo» del individuo, sino también de las sociedades, ya que «todas las sociedades para definirse como tales, han simbolizado, marcado, normativizado el espacio que pretendían ocupar - del mismo modo que han simbolizado el tiempo, observado las irregularidades del calendario, el ciclo estacional e intentado dominar intelectualmente los azares de la meteorología ${ }^{67}$. Si es verdad, como afirma Augé, que el hombre instala las señas de identidad, de relación y de historia, en la dialéctica entre el cuerpo y el territorio, y es ahí donde se manifiesta su reconocimiento ${ }^{68}$, también es verdad que el hombre, cuando forma comunidades, determina que la comunidad misma busque los mismos parámetros, para afirmarse y reconocerse: es en la virtualidad del ciberespacio, que en cierta medida es una renuncia a la corporeidad, que los hombres guardan la misma referencia estructural como se realiza en la conexión o en la intersubjetividad de las formas de pensamientos. La conexión de mentes en el ciberespacio es, en cierta medida, una renuncia a la corporeidad. Así, la vuelta a la "tribu», con su característica darwiniana — más bien nietzscheana, freudiana, marxista ${ }^{69}$-, no sería nada más que la misma estructura —o más bien forma- de pensamiento que gobierna la vida natural y lo que representa la metáfora de la vida natural — propiamente, el significado de las «cosas» que está detrás de las formas de las «cosas» ${ }^{70}$.

65. Véase Castells, Manuel, La galaxia Internet..., ob. cit., p. 235.

66. Cfr. Marina, José Antonio, Crónicas de la ultramodernidad, ob. cit., p. 103 y s.

67. Véase AugÉ, Marc, El sentido de los otros: actualidad de la antropología, Barcelona, Paidós, 1996, p. 125 , p. 99.

68. Cfr. ibídem, p.102.

69. Foucault, Michel, Nietzche, Freud, Marx, ob. cit., p. 23 y s.

70. Cfr. Foucault, Michel, Las palabras y las cosas. Una arqueología de las ciencias humanas, Buenos Aires, Siglo XXI, 1968, p. 375, p. 43, p. 49, p. 72, p. 273, p. 296, p. 322 y s. Cfr., en sentido parecido, VATTIMO, Gianni, Il soggetto e la maschera: Nietzsche e il problema della liberazione, Milán, Bompiani, 1974, p. 382, p. 226 y s. 
Que la relación entre corporeidad y virtualidad no determina la desaparición de las mismas estructuras del pensamiento es evidente, porque las nuevas tecnologías, con la posibilidad de interacción, quieren salvaguardar esta misma estructura para no alejarse de su tiempo. Además, el recorrido invertido que apunta a la orientación social para reducir la desorientación individual es una consecuencia de las consideraciones siguientes.

Según De Kerckhove, existen cuatro impactos de la tecnología interactiva que se producen sobre la imagen del cuerpo y de lo que él denomina, el «envoltorio físico»: la telecepción, la expansión, la múltiple personalidad y la propiocepción $n^{71}$. La telecepción hace referencia al alcance sensorial que nos proporcionan las tecnologías interactivas y que añade una nueva dimensión a nuestra vida sensorial biológica. La expansión es un fenómeno que se produce al mismo tiempo y que se basa en cómo las tecnologías interactivas nos producen un sentido de pérdida de los propios límites corporales concretos. La múltiple personalidad se refiere a cómo la pérdida de un sentido claro de nuestros límites físicos, la expansión de nuestros marcos mentales, la redistribución en línea de nuestros poderes de acción, contribuye a crearnos una imagen confusa del cuerpo. Por último, la propiocepción es una respuesta del ser humano a esa duda sobre su corporeidad. La necesidad de saber que el propio cuerpo sigue ahí, lleva a los hombres a realizar actividades que les permitan volver a entrar en contacto con su propio cuerpo, para así aumentar su acceso a sensaciones físicas, sólo para saber cuál es su situación ${ }^{72}$. Ahora bien, se trata de recrear el individuo descompuesto y fragmentario a través de un no lugar. Este no lugar, o topo $i$ virtual ${ }^{73}$, es propio de la ultramodernidad o de la sobremodernidad y se caracteriza por un exceso de tiempo, exceso de espacio y exceso de individualismo ${ }^{74}$ - por lo que se refiere a la reproducción de las constantes de su vida corpórea- Estas tres figuras del exceso se manifiestan claramente en los nuevos medios de comunicación ${ }^{75}$. Virilio destaca como hasta hoy los acontecimientos tenían lugar en tiempos y espacios locales y como la mundialización y la virtualización instauran en cierto modo un tiempo mundial, y como éste prefigura un tipo nuevo de tiranía. Para Virilio, la riqueza de la historia tenía su base en la diversidad de lo local, y ahora la historia se va a desarrollar en ese tiempo único universal que es lo instantáneo ${ }^{76}$. Y, paralelamente, la

71. Cfr., de esta forma, De KerCKHOVE, Derrick, Inteligencias en conexión..., ob. cit., p. 72 y s.

72. Cfr. ibídem, p. 75 y s.

73. Así, Augé, Marc, Los no lugares, espacios del anonimato: una antropología de la sobremodernidad, Barcelona, Gedisa, 1993, p. 125, p. 24 y s.

74. Cfr. ibídem, p. 35 y s. Cfr., en sentido parecido, Marina, José Antonio, Crónicas de la ultramodernidad, ob. cit., p. 82 y s.

75. De esta forma, De KercKHOVE, Derrick, Inteligencias en conexión...,ob. cit., p. 123 y s. En sentido parecido, cfr. SARTORI, Giovanni, Homo videns.., ob. cit., p. 212 y s.; y cfr. CASTELLS, Manuel, La era de la información..., ob. cit., p. 16 y s.

76. Según Virilio, «[...] por primera vez, la historia se va a desarrollar en un tiempo único: el tiempo mundial», véase VIRILIO, Paul, «Peligros, riesgos y amenazas», en RAMONET, Ignacio (ed.), Internet, el mundo, ob. cit., p.157. 
mediatización de los hechos acelera nuestra vida convirtiendo el presente en historia; el futuro, en realidad posible.

Contrariamente a lo que escribe Auge ${ }^{77}$, los no lugares no son lugares de nadie y, en realidad, tampoco los no lugares físicos en que no se reconocían identidades - imaginamos en período de guerras, países conquistados, ciudades vaciadas por epidemias, países desmembrados por conflictos culturales ${ }^{78}$ _ , sino los lugares del más hábil, del más fuerte físicamente tal vez, según las características morfológicas de los lugares, del más inteligente, del más sabio, del más carismático, etc.; los no lugares son siempre lugares de los que imponen la capacidad que tienen más, respecto a los demás, y según las necesidades propias del lugar: una combinación entre fuerza y metáfora, entre actuación y moral, entre información y comunicación. Los no lugares son los lugares de todos y de algunos en particular ${ }^{79}$. El no lugar se forma también cuando existe un exceso de espacio. El exceso de espacio se produce cuando el espacio deviene imagen. La posibilidad de ver y vivir hechos que ocurren en otras partes del mundo en tiempo real a través de los medios, hace que la aldea global de McLuhan sea una realidad que las tecnologías de la instantaneidad nos recuerdan constantemente. El mismo no lugar crea el poder social considerado que desde nuestros televisores somos mirados por todo el que asoma desde los medios. Kerckhove decía que «tú no miras a la televisión, ella te mira a tí» ${ }^{80}$.

77. Afirma Augé: «[...] en los no lugares nadie se siente en su propia casa, pero tampoco en la de los demás» y prosigue "[...] en primer lugar, las nociones de lugar y de no lugar son, evidentemente, nociones límite. Existe un no lugar en todo lugar, del mismo modo que en todos los no lugares pueden recomponerse algunos lugares. Dicho de otra forma: lugares y no lugares corresponden a espacios muy concretos, pero también a actitudes, a posturas, a la relación que los individuos mantienen con los espacios que habitan o recorren». De esta forma "[...] el no lugar es el espacio de los otros sin la presencia de los otros, el espacio constituido en espectáculo, espectáculo ya tomado en las palabras y los estereotipos que lo comentan por adelantado en el lenguaje convenido del folclore, de los pintoresco o de la erudición", véase AUGÉ, Marc, Hacia una antropología de los mundos contemporáneos, Barceloma, Gedisa, 1995, p. 105; cfr., en sentido parecido, AUGÉ, Marc, Los no lugares, espacios del anonimato..., ob. cit., p. 16 y s.

78. Cfr. Huntington, Samuel P., El orden político en las sociedades en cambio, Barcelona, Paidós, 1997, p. 404, p. 33 y s., p. 79 y s. 2a ed., con presentación de Oscar Oszlak (1a ed. 1972), cfr. Coser A. Lewis, Las instituciones voraces, México, Fondo de Cultura Económica, 1978, p. 153.

79. Sobre esto, cfr. VIRno, Paolo, Gramática de la multitud..., ob. cit., p. 72 y s., cfr., en sentido no diferente, MALDONADO, Tomás, Entre lo real y lo virtual, ob. cit., p. 213-217. Es justo recordar la célebre norma final, solución y desvelamiento material de las aparentes normas comunistas, que Orwell atribuyó a los animales cuando se realizó la paz tras la rebelión: «Todos los animales son iguales, pero algunos son más iguales que otros», véase ORWELL, George, La fattoria degli animali, traducción de Bruno Tasso, Roma, Gruppo Editoriale L'Espresso, 2002, p. 56, p. 111, p. 119.

80. Véase De KerCKHOVE, Derrick, La piel de la cultura: investigand..., ob. cit., p. 41. 


\section{Reinventar el espacio desde lo social: un reto sociológico}

Así, la ordenación de lo social reproduce o perfecciona, según como ha sido realizada la ordenación, el cambio de nuestra realización en el mundo que hace que también varíe nuestra relación con nosotros mismos. Reinventar el espacio desde lo social y no desde la individualidad podría ser el camino a través del cual se podría realizar el proyecto denominado ultramodernidad, porque es un proceso lógico no lineal, sino dialéctico, que cuando se hable de globalización, se hable también de glocalización ${ }^{81}$, cuando se habla de universal aparece la experiencia individual ${ }^{82}$, cuando se habla de poder y de dominio - algo que inevitablemente se ejerce sobre alguien o las masas- aparece también el problema de la alteridad —en su dúplice aspecto como algo propio de quien domina y algo propio de quien es dominado ${ }^{83}$. Ésta es la clásica distinción semiótica entre proceso y campo o, como afirma Contreras, entre espacio de los flujos y espacio de los lugares: «Los canales de difusión de los símbolos presentan una bipolaridad emergente: el espacio de los flujos y el espacio de los lugares. El primero corresponde al territorio de la función, del poder de unos pocos: las grandes empresas financieras, las industrias de alta tecnología, de los medios de comunicación, de las redes criminales, del mercado negro de armas; es, en resumidas cuentas, la dimensión global de la sociedad humana. Por el contrario, el espacio de los lugares es un espacio local reservado a la identidad propia de individuos o grupos donde se manifiestan naturalezas pri-

81. Cfr., sobre este concepto, BECK ULRICH, ¿Qué es la globalización? falacias del globalismo, respuesta a la globalización, Barcelona, Paidós, 1998, p. 224, p. 77 y s.; cfr. ROBERTSON, Roland, "Globalización: tiempo-espacio y homogeneidad-heterogeneidad», Zona Abierta, 2000, n. 92-93, p. 213-242, disponible en <http://www.cholonautas.edu.pe/busca.php?busca= glocalizacion>.

82. Cfr., en este sentido, Dussel, Enrique, La ética de la liberación. Ante el desafio de Apel, Taylor y Vattimo con respuesta crítica inédita de K.O. Apel, Universidad Autónoma del Estado de Mexico, 1998, p. 34.

83. Cfr., en este sentido, VatTimo Gianni, Il soggetto e la maschera..., ob. cit., p. 35 y s. Por eso no se comparte la consideración de Augé: «No es pues extraño que, a fin de cuentas, hoy día nos cueste pensar en el espacio y en la alteridad. El espacio es la evidencia. Vivimos en una época donde se crean grandes espacios económicos, donde se esbozan grandes agrupaciones políticas, donde las multinacionales y el capital transgreden las fronteras con una alegría capaz de preocupar a más de un marxista nostálgico y donde, simultáneamente, los imperios se hunden, los nacionalismos se exacerban y, a una escala más reducida, donde se multiplican los museos locales, la referencia a las identidades locales más minúsculas, la reivindicación del derecho a trabajar en el país». Véase AUGÉ, Marc, Hacia una antropología de los mundos contemporáneos, ob. cit., p. 107-108. En realidad, es automático pensar en la alteridad en un contexto espacial, los espacios libres no existen. Esto depende de lo que se entiende por no lugar, obviamente. Pero, como demuestra el fenómeno de la glocalización, propio cuando el espacio es común a todos, emerge quien quiere reivindicar su propia independencia y autonomía sobre aquel espacio. Ante el temor de perder, vuelve el ansia de dominio, surgen las identidades locales, se enfrentan a la polipragya para recrear y afirmar una propia identidad local. Nunca como ahora el ansia de dominio sobre un espacio de todos surge con fuerza para evitar que desaparezca quien creía poseer aquel espacio y sus tradiciones contextuales. 
marias: religiones, razas o nacionalidades» ${ }^{84}$. En la ultramodernidad, se trataría, entonces, de partir del sentido de la sociedad para llegar a orientar el sentido desorientado de los hombres aislados corporalmente, pero unidos en la virtualidad. Así, también la navegación por Internet no es más que un ejemplo de lo que tiende a convertirse nuestra relación con el otro en el mundo contemporáneo: una relación abstracta, en la medida en que pasa por la espectacularización del otro; espectacularización mediática a través de todos los mensajes y todas las imágenes que nos dan tanto la sensación de estar presente en la vida cotidiana, como la de no estar presente en aquélla, sino en la historia: que las informaciones buscadas, tal vez sencillas, llegan a ser descubrimientos en nuestro círculo de colegas, el saber procesar el lenguaje de la información se convierte en posibilidad de espectacularización, el poder de hablar, de decir, de influir, o de creer influir: en pocas palabras, de estar y de ser, aunque en lo virtual que mañana podría ser que ya no estuviera.

\section{Conclusión}

Hace algunos años, se rodó una película sumamente interesante y que abrazaba agradablemente el mundo de lo real, ofreciendo una terrible visión del futuro del mundo virtual capaz de regenerar y reinventar el primero: The Matrix ${ }^{85}$.

Matrix representa un juego de simulación de la realidad (simular no es reinventar). Y la simulación puede determinar lo que dijo Slavoj Zizek: «Aquí podemos ver en qué sentido The Matrix (la película) estaba en lo cierto: la realidad que abandonamos está tan regulada por la super poderosa e invisible red digital que su colapso puede crear una "real" desintegración global. [...] si estuviéramos a punto de ser privados de la red digital artificial que interviene y sostiene nuestro acceso a la realidad, no encontraríamos vida natural en su verdad inmediata, sino la insoportable tierra baldía. “ ¡Bienvenidos al desierto de lo real!”, como es irónicamente felicitado Neo, el héroe de Matrix, en el momento en que ve la realidad tal como es, sin el Matrix» ${ }^{86}$. En este contexto, la simu-

84. Véase Contreras, Fernando R., Nuevas fronteras de la infografía..., ob. cit., p. 56.

85. Matrix, que significa 'matriz', tiene dos significados, uno filosófico y otro más técnico. Por un lado, hace referencia a la matriz donde están los fetos. Como si la realidad conocida fuera semejante a esa matriz, sin la cual, al igual que el feto, no podríamos sobrevivir. Dependemos de la matriz, somos unos pequeños seres desprotegidos, sin conciencia ni siquiera de donde estamos. Y, por otro lado, está el significado de matriz matemática. Se supone que la matriz filosófica anterior está construida a base de algoritmos y estructuras matemáticas, como las matrices matemáticas. La película Matrix insinuaba que todo lo que veíamos eran sólo datos de un ordenador (de hecho, en la película aparecen varias imágenes pantallas con números cayendo formando una especie de matriz matemática, las famosas letras verdes bajando por la pantalla). Esos datos se guardan, en informática, en una matriz de datos.

86. Véase ŽıŽEK, Slavoj, en «Bienvenido a lo desierto de lo real», consultable en <http://alepharts.org/pens/desierto.html>. En otro artículo, el mismo autor sostiene que «[...] la película no se equivoca al insistir en que hay una realidad tras la simulación de Realidad Virtual» en «The Matrix, o las dos caras de la perversión», en Acción Paralela, n. 5, disponible en 
lación es una metáfora aparentemente verdadera de la realidad, pero no logra asumirla por completo - la película parte del hecho que existe un margen de error y de imperfección. Todo el juego de la película está determinado por una desviación del conocimiento, un espejismo de posibles y probables realidades que impone aún más la necesidad de reinventar la realidad y el nuevo espacio en el que vivimos partiendo de lo social. Slavoj está de acuerdo en esto: "Sin embargo [en la película] lo real no es la "verdadera realidad" tras la simulación virtual, sino el vacío que hace que la realidad sea incompleta/incoherente, y la función de cada Matrix simbólica es disimular esta incoherencia. Una de las maneras de ocultarla es, precisamente, declarar que, detrás de la realidad incompleta e incoherente que conocemos, hay otra realidad que no está estructurada alrededor del callejón sin salida de la imposibilidad ${ }^{87}$.

Volviendo al principio, las palabras de Sartori se aplican al Homo sapiens y al Homo videns, pero no al Homo sapiens et videns, porque éste sabe ver, mientras que el primero sabe solamente, y el segundo ve solamente. Los desinformados, los nuevos marginados, los pobres de poder del mundo virtual, son bien los que no saben pensar por imágenes, bien los que viven por imágenes, porque ambos no saben ver las imágenes, interpretarlas; ven únicamente el resultado de la información y no la fuente de la comunicación: las mismas fuentes que ofrece el sentido metafórico de las «cosas»; no saben encajar el mensaje en el espacio-tiempo adecuado, lo virtual y lo real; no saben ver las estructuras comunes al mundo virtual y al mundo real, ni tampoco saben reproducirla en el mundo virtual. Y esto porque, además, no es el proyecto del hombre particular, de la individualidad, del nibil dentro del todo, sino el proyecto de una masa organizada, que utiliza la fragmentación para agregar, que utiliza la instantaneidad para llamar la atención, que utiliza la proyección de conceptos para lanzar un mensaje a algunos y no a todos. Una masa de individuos, un cuerpo social, que, con su capacidad de ver, podrá dar sentido al sujeto individual deseoso de entrar en ella, de poder pertenecer a una tribu. De esta forma, el proyecto de la ultramodernidad llega a ser el camino de todos, aunque empujado materialistamente, en parte dionisiacamente, subvirtiendo el orden establecido anárquicamente. Esto porque el mundo virtual guarda las mismas estructuras de pensamientos que la sociedad real, aunque de forma invertida.

<http://accpar.org/numero5/matrix.htm>. Cfr. también ŽIŽEK, Slavoj, Bienvenidos al desierto de lo real, Madrid, Akal, 2005, 128 p.

87. "Con la coincidencia en la era posmoderna del "fin de la historia" con la total disponibilidad del pasado en memoria digital, en esta época en que vivimos la utopía atemporal como una experiencia ideológica diaria, la utopía se convierte en una añoranza de la Historia Real en sí misma, de la memoria, de retazos del pasado auténtico». Véase ŽıžEK, Slavoj, "The Matrix, o las dos caras de la perversión», ob. cit. La solución no consiste en «alterar las normas de nuestra prisión mental» (Zizek), sino en aceptar y analizar las nuevas formas de comprensión del mundo (más bien sumergirnos en una didáctica de formas de pensamiento) y realizar el proceso histórico de adaptación natural con inteligencia, observación y dando relevancia al momento comunicativo. 